\title{
DEPARTMENT OF SCIENTIFIC AND INDUSTRIAL RESEARCH, NEW ZEALAND
}

\section{ANNUAL REPORT}

$\mathrm{T}$ HE nineteenth annual report of the Department of Scientific and Industrial Research, Now Zealand (Wellington: Government Printer. 1s. 6d.), covers the frop 1944-45, and includes the Minister's statemeny we secretary's report and reports of the Xespond Committees of the Council as well as of tile dawthron Institute, the work of the Dominion IA Aoratory, Observatory and Physical Laboratory, the Geological Survey and Magnetic Observatory, the Meteorological Branch and research work at Canterbury and Massey Agricultural Colleges.

Research during the year under the Building Research Committee embraced the study, and methods of control, of timber-infesting insects and fungi, carried out by the Plant Diseases Division, the Entomology Division and State Advances Corporation; the causation and control of mould infestation in houses ; investigations of a system of prefabrication in standard concrete and light-weight (pumice) concrete and a review of literature on the acousties of building, preparatory to carrying out experimental work with particular reference to multiwall units. The Committee also considered a report by the New Zealand Institute of Architects on proposals for earthquake reconstruction in earthquake danger zones, and recommended a national survey of all buildings to determine their structural stability under earthquake stress.

The Dairy Research Institute continued its work in collaboration with the Entomology Division of the Plant Research Bureau on the control of cheesemite; trials with dichloroethyl ether have shown great promise as a means of control in curing rooms. Isolated starter-rooms and other devices designed to exclude airborne bacteriophage infection of starter culture for cheese manufacture continued to give success in the maintenance of cultures. Trouble due to failure of acid development in the cheese vat still occurs due to infection of the factory equipment and infection of the milk delivered from cans which have been used for the transport of whey. The former infection is easily checked by chlorinating the vats, pasteurizer and piping, but the contamination of the milk cans is much more difficult to eliminate. Chlorination of the whey proved practicable but costly. Other investigations covered the effect of the feeding of cows on the characteristics of cheese, milk, dairy cow nutrition and growth-hormone studies, and the value of various irrigants in the treatment of mastitis.

The Food Preservation and Transport Advisory Committee's investigation on the refrigerated gas storage of apples, superficial scald on Granny Smiths, the influence of rootstock and intermediate scion on core-flush in Granny Smiths and the effect of fertilizers on the cold-storage quality of apples were taken a stage further. Fruit research included long-term manurial investigations, small-scale trials of D.D.T. and other insecticides for control of carrot aphids, red-mite, codling moth, etc.

A Manufacturer's Research Committee was established to survey the present state of New Zealand manufacturing industry in the light of modern scientific developments, to consider plans for con- certed efforts to meet the demands of the post-war period, as well as methods for the application of science in development, extension and modernization of existing industries and to encourage the formation of research associations in appropriate industries, the employment of technical assistance in industry and the investigation of particular industrial problems by the Department of Scientific and Industrial Research or other scientific institutions.

In the Plant Chemistry Laboratory the preservation of food by dehydration received most attention, vegetables and apples being the subject of most of the work, though some work was carried out on stonefruits and with pears. Work continued at the Plant Research Bureau on linen flax, and in the Botany Division on seaweed resources and weed investigations. Plant disease investigations by the Plant Diseases Division covered the bacterial wilt of beans, carrot rust-fly and tests of inert dust to protect stored grain from weevil attack, as well as preliminary work on the production of penicillin. The. Wheat Research Institute evolved a now wheat strain, equal in yield to Cross 7 but with a considerably higher baking score and protein content, while milling practice was improved so as to ensure higher food value being secured from the flour produced. Tobacco research resulted in a considerable measure of control being secured in the field over mosaic disease, and showed that high-quality seed can be produced locally, rendering New Zealand independent in this respect.

An important experiment in North Auckland in evaluating the soil maps in relation to the factors concerned in economic management, production and potential land use showed that the soil survey has enormous potentialities. At the Cawthron Institute, in addition to soil survey work, tomato investigations included the use of steam and formaldehyde for treating glasshouse soil and tests of soil disinfectants on outside tomato soil. At the Canterbury Agricultural College the effect of fertilizer treatment on the production of subterranean clover continued. Entomological investigations there included sheep-dipping trials, trials for the control of stem weevil and Hessian fly on wheat. At the Massey Agricultural College sheep nutrition experiments have continued both as research into animal nutrition and on the parasitology of sheep.

As a result of discussions on the functions of the Dominion Physical Laboratory, it has been recommended that the post-war function of this Laboratory should be such that its decision on physical matters of precision, quality and performance be accepted as final; its functions are more specifically stated as general research and development of a physical and engineering nature; calibration and repair and general testing of civil, mechanical and electrical equipment; work for the New Zealand Standards Institution and general physical testing of goods and commodities and the custody and control of the legal physical standards of measurement. A feature of the year's work was the increasing number of requests for assistance made to the Laboratory by industry. 